\title{
Urban Bus Services in Developing Countries and Countries in Transition: A Framework for Regulatory and Institutional Developments
}

\author{
Brendan Finn, ETTS Ltd \\ Corinne Mulley, University of Sydney
}

\begin{abstract}
Urban passenger transport has experienced major change in many developing countries in Africa, Asia, and the Middle East, as well as in countries of political and/or economic transition in the Commonwealth of Independent States (CIS) and China. Such changes have included planned market opening to private operators and new entrants; unplanned market opening by the entry of unlicensed operators; privatization and other changes to the ownership base of large public-sector transport companies; emergence of large-scale minibus and paratransit; and national and urban policies and programs to upgrade the transport supply and quality.

This paper presents a framework to understand regulatory and institutional changes in urban bus services in Africa, Asia, the Middle East, the CIS, and China. The framework identifies three types of changes: (i) changes in the role of the regulator and market structure; (ii) changes in the structure of the operator and of private sector participation; and (iii) changes in the transport supply. The paper then identifies critical factors leading to change in the urban transport sector, factors that can be identified with successful outcomes, and issues associated with the development of the minibus, paratransit, and the informal sector that have played major roles in the urban transport sector of developing countries and countries in transition.
\end{abstract}




\section{Introduction}

The mobility of people is fundamental to their ability to participate in society. In developed countries, mobility in urban areas is assured for the majority of the population, in part due to high levels of car ownership, and in part due to stable public passenger transport systems. In the urban areas of most developed countries, public transport is provided by public or private operators who have medium- to longterm agreements with a transport authority for a defined set of services, enforced legal protection against interlopers, and are usually subsidized to cover any losses due to the social and environmental dimensions of the services.

The situation in developing countries and countries in transition is more varied. For working purposes in this paper, "developing countries" are considered as those with a low average income and a low degree of industrialization. "Countries in transition" is used to include countries in which there have been major political and market shifts such as the Commonwealth of Independent States (CIS or former Soviet Union countries), changes to the structure of the economy (such as China), or fundamental change in the demographic or settlement patterns such as India's and China's migration to urban areas, and where institutions, markets, laws, and other frameworks are still in the process of adapting. Some countries can be both developing and in transition.

By their very nature, these countries, which account for the majority of the global population, face diverse challenges that involve change to society, economic and legal frameworks, and relationships between these (UITP 2003, Amos 2004, UN 2005). Further, many of these countries lack the financial resources, appropriate political/government structures, and sometimes the political stability to implement effective and efficient mobility services at affordable prices that meet the expectations of citizens (World Bank Group, 2008). These challenges are most concentrated in the urban areas and their hinterlands due to the scale of population and the intensity of activity.

There may also be extreme problems caused by lack of mobility for individuals and communities in rural areas, where it is estimated that 1 billion people in low-income countries have no access to an all-weather road (World Bank Group 2008).

The market for urban passenger transport has experienced major change in many developing countries in Africa, Asia, and the Middle East for a variety of economic, political, and societal reasons and due to fundamental political and economic transition in CIS and China. Such changes have included planned opening of the market 
to private operators and/or new entrants; unplanned opening of the market by the entry of unlicensed operators, especially where the licensed services become inadequate; privatization and other changes to the ownership base of large publicsector transport companies; emergence of large-scale minibus and paratransit; and national and urban policies and programs to upgrade the transport supply and quality.

This paper concentrates on developments in the urban bus services sector in developing countries and countries in transition that have recently occurred or which are currently taking place. The contribution is specifically to critically synthesize these changes which impact on both the mobility of the citizens and on the ability of the authorities and other stakeholders to influence the coverage, connectivity, intensity, and quality of mobility services that are available. This contrasts with the existing literature that either concentrates on a more macro approach (Amos (2004) or presents evidence from a single location.

For the purposes of this paper, the urban passenger transport sector can be considered to consist of three strands:

- Agencies that manage the market for the supply of transport services, which are referred to as "the regulator" (this includes transport authorities)

- Entities of public and private form that operate the transport services, which are referred to as "the operator"

- The transport offer, including the network, service types, coverage, intensity, and quality

The paper presents a framework to understand the three main types of development observed:

1. Changes to the market structure and the role of the regulator, and the basis of the relationships between the regulator and the operator

2. Changes to the nature, format, ownership, and structure of the transport operators and means of participation of the private sector

3. Changes to the type, structure, quality, and scale of passenger transport services.

The current paper focuses on positive developments; the approach has been to identify relevant developments from available published sources, supplemented by direct observation. A good analysis of failings and what to avoid is provided by Gwilliam (2003). 
Since most of the developments are ongoing and are themselves changing, the focus has been on contemporary sources. Much of the evidence is drawn from papers presented at the Thredbo series of conferences on competition and ownership in passenger transport, a major source of information in this sphere, while unreferenced items are from the authors' direct experience.

Following an introduction to international trends in market structures and the role of the regulator, with emphasis on those in more mature systems, each of the three strands is considered in turn.

The final section discusses issues arising from the presented developments and key factors and/or enablers for evolution of an effective passenger transportation system.

\section{International Trends in Market Structures and Regulatory Frameworks}

Over the past two decades, there has been a very clear trend towards a more structured market for the provision of urban public transport. This section is derived from more extensive reviews by Finn and Nelson (2003a, 2003b). The main features include:

- restructuring institutional frameworks as a coherent supporting structure

- a clear separation of planning and operational functions

- opening of the markets to allow new entrants to offer services

- procuring subsidized services by transport authorities, using market processes

- corporatization of formerly public-sector operating entities, i.e., transformation into entities that are structured as companies with associated corporate, governance and accounting principles

- privatization, joint-ventures, and other means of modifying the ownership base of parastatal operators

- making public assets available to both public and private sector bidders

- mobilizing private investment for public infrastructure and services

These trends and motivations have led to different market frameworks emerging, with greater or lesser opportunities for transport operators to participate and with different relationships between the authorities and the operators. The market framework in a specific location usually reflects historical context, the national and local policies, and the capacity of the local government. In more mature systems, the various issues of policy, planning, development, and integration of passenger 
transport, regulation, financing, etc., are handled by a transport authority either for the urban area or for a broader metropolitan area (Nielsen et al. 2005). The transport authority is usually accountable to the governance structures of the local government, but it can be at regional or national level.

\section{Framework for Understanding Change in Urban Public Transport in Developing and Transition Countries}

This paper concentrates on the connections between changes to the regulatory framework, changes to the nature and form of the operator, and the nature of transport supply. Examples of these are presented, then summarized in Tables 1, 2, and 3 in the following sections of this paper. These elements are clearly interconnected, and developing countries and countries in transition do not show a unique response. One common characteristic of the experience of developing countries and countries in transition is that the frameworks in which the urban transport sector exists change, and often change rapidly. In some cases, the main reason is because society itself is changing. In other cases, it is because a framework is lacking or contains inherent weaknesses that need to be adjusted. In contrast, in mature systems where the frameworks are stable, there is often no fundamental change for decades, and all participants understand the roles, relationships, opportunities, and boundaries among the various stakeholders (functionally and spatially).

\section{Change in the Role of Regulator/Transport Authority and Market Structure}

Regulation of urban passenger transport is introduced or restored. In Ghana, the passenger transport sector had been self-regulating since 1983, as the minibuses became the dominant form of transport supply while the state-owned Omnibus Service Authority (OSA) went into decline and was unable to meet growing demand. In 2008, the function of regulation was restored to Local Government. Bylaws were passed in each area to provide the legal basis (Finn 2008, 2009). In Manila (Philippines), while route franchising remains with LTFRB, since 2003 the city authority (Metropolitan Manila Development Authority, MMDA) regulates the flow of buses along the principal urban orbital (EDSA) and at both their terminals and stopping places along EDSA.

Regulation of passenger transport transferred to City. In Jordan, the Land Transport Regulatory Commission (LTRC) of the national Ministry of Transport is the regulator for all passenger transport services throughout the country. In November 2007, all responsibility for urban passenger transport in Amman, including the regulatory 
role, was transferred to Greater Amman Municipality. LTRC continues to regulate services elsewhere in the kingdom.

Regulatory capacity is developed within local government. In Accra and Kumasi (Ghana), Amman (Jordan), and Tbilisi (Georgia), new municipal public transport departments have been established or existing general transport departments have been restructured to add public transport responsibilities. Specific public transport and regulatory expertise is engaged and developed (Finn 2008). For example, in Manila, the MMDA has developed a specific public transport unit, regulations, staffing, and supporting technical systems to manage the bus routes operating on EDSA, the megalopolis's primary ring road (30+ routes, 3000+ buses, $\sim 50,000$ daily bus trips). This system is called the Organised Bus Routes (OBR).

Changes are made to rules for market entry and/or procurement. Lagos (Nigeria) has and Accra will procure bus and feeder bus services for a BRT scheme under tendering, awarding route service contracts to the successful applicants. In Tbilisi, in 2001, the unregulated minibus operators were formalized by opening a competitive tender process and awarding operating permits to operators, who, in turn, were required to organize themselves into operating entities (some 64 entities were formed).

Regulators develop new models for procurement of services. In Recife (Brazil), a new model for competitive tendering has been developed to overcome three decades of wrangling among different government agencies. It established a basis for a specified service, regulation of quality, and financing (Filho 2007). This has been the basis to admit some 252 vehicles on 26 new lines that had previously been in direct competition with the state-owned transport operator.

Regulators develop new contractual basis for bus services or amend existing ones. In Kaunas (Lithuania), as part of major restructuring of the reorganization and finances of the municipal bus and trolleybus companies, the City entered into a 10-year public service contract with the municipal company based on committed service levels and quality, subsidies, and investment program (Bruggeman 2009). In South Africa, a system of contracts was established with private bus operators for subsidized commuter bus services. In total, there are about 115 such contracts, with differing payment bases. The government is currently attempting to amend all contracts to payment for kilometres operated (Walters 2009). In Santiago de Chile, as part of the TranSantiago BRT system, a new contractual and payment system was established for the operators so that they would participate in the integration of network and tariffs (Muñoz 2007). 
Regulator makes direct intervention to restructure operator sectors. In Sri Lanka, in 2005, the 11 regional state public owned and operated bus companies were reformed into a single national entity, SLTB (Sri Lanka Transport Board). There are also approximately 19,000 private bus operators in addition. The National Transport Commission has initiated five pilot projects to cluster the private operators in pilot areas, to improve their organizational capacity, use of resources, and service quality (Kumarage and Jayarante 2007).

Transport authority makes vehicles available to operators. In Accra and Tbilisi, the transport authority or government acquired vehicles for the (quasi-) public sector bus operators that had all but ceased to have operational capacity. This allowed them to re-establish large-bus operations. The vehicles were initially second-hand buses that had limited benefit and many of these vehicles soon ended up out of service (Finn 2008). Subsequent purchases acquired new buses. In Dhaka (Senegal), the transport authority used government-negotiated loans to establish a special purpose company to acquire vehicles and lease them to private sector operators who agreed to be regulated and to operate under contract (IBIS 2008) in return.

Transport authority provides funding or financial incentives for bus purchase and/or technology upgrades. The City of Kaunas arranged financing through EBRD for the purchase of new buses and associated support systems for the municipal bus company (Bruggeman 2009). In South Africa, a scrappage grant has been implemented to incentivize bus operators to replace old vehicles, equivalent to about one sixth of the cost of a new vehicle (Walters 2009). In many rural areas in Brazil, school transport involves long journeys in difficult operating conditions. The Brazilian government has sponsored the development and deployment of more robust and suitable vehicles (Carvalho et al. 2009).

Transport authority finances new transport infrastructure to enhance public transport system and provide suitable facilities to operators. In Accra, Amman, Dar es Salaam (Tanzania, planned), Delhi (India), Mauritius (planned), and many other cities, the transport authority has funded or plans to fund the development of Bus Rapid Transit infrastructure and supporting facilities to improve the quality and level of service of passenger transport (Richmond 2006, Torres 2007, Finn 2008 2009). In China, many municipalities have constructed passenger interchanges, terminals, and overnight parking for use by corporatized state-owned operators (Dotson and Finn 2007). In Amman, the municipality has constructed bus and shared taxi terminals for private operators (Finn 2009).

Table 1 presents a summary of these changes. 


\section{Table 1. Summary of Changes in Role of Regulator/Transport Authority and Market Structure}

\begin{tabular}{|c|c|}
\hline $\begin{array}{l}\text { Change in Role of Regulator/Transport Authority } \\
\text { and Market Structure }\end{array}$ & Examples \\
\hline $\begin{array}{l}\text { Regulation of urban passenger transport introduced or } \\
\text { restored }\end{array}$ & Ghana, Manila (Philippines) \\
\hline Regulation of passenger transport transferred to the City & Jordan \\
\hline Regulatory capacity developed within local government & $\begin{array}{l}\text { Accra and Kumasi (Ghana), } \\
\text { Amman (Jordan), Tbilisi } \\
\text { (Georgia), Manila (Philippines) }\end{array}$ \\
\hline $\begin{array}{l}\text { Changes made to rules for market entry and/or procure- } \\
\text { ment }\end{array}$ & $\begin{array}{l}\text { Accra(Ghana) and Lagos } \\
\text { (Nigeria), Tbilisi (Georgia) }\end{array}$ \\
\hline Regulators develop new models for procurement of services & Recife (Brazil) \\
\hline $\begin{array}{l}\text { Regulators develop new contractual basis for bus services, or } \\
\text { amend existing ones }\end{array}$ & $\begin{array}{l}\text { Kaunas (Lithuania), South Africa, } \\
\text { Santiago (Chile) }\end{array}$ \\
\hline $\begin{array}{l}\text { Regulator makes direct intervention to restructure private } \\
\text { operators }\end{array}$ & Sri Lanka \\
\hline Transport authority makes vehicles available to operator & $\begin{array}{l}\text { Accra(Ghana), Tbilisi (Georgia), } \\
\text { Dhaka (Senegal) }\end{array}$ \\
\hline $\begin{array}{l}\text { Transport authority provides funding or financial incentives } \\
\text { for bus purchases and/or technology upgrades }\end{array}$ & $\begin{array}{l}\text { Kaunas (Lithuania), South Africa, } \\
\text { rural areas in Brazil }\end{array}$ \\
\hline $\begin{array}{l}\text { Transport authority finances new transport infrastructure } \\
\text { to enhance public transport system quality and level of } \\
\text { servce and to provide improved operating and maintenance } \\
\text { facilities to operators }\end{array}$ & $\begin{array}{l}\text { Accra (Ghana), Amman (Jordan), } \\
\text { China, Dar es Salaam (Tanzania), } \\
\text { Delhi (India), Mauritius, many } \\
\text { other cities }\end{array}$ \\
\hline
\end{tabular}

\section{Change in Form of Operator}

Public sector bus operators have their corporate and ownership basis changed. In China, the State Owned Enterprise bus companies in many cities have been transformed from administrative units of the municipality into joint-stock companies, and inward investment is now accepted either as direct investment or through the creation of joint-ventures (Dotson and Finn 2008). In Kazakhstan, the first wave of public transport reform in 1996-7 allowed municipalities to privatize their transport companies and to allow new market entrants. Most cities, apart from Almaty and Astana, privatized their bus companies. All cities allowed new market entrants (Finn 2005). In Tbilisi, the municipal bus company has been transformed into a corporate entity, placed at arms-length from the municipality, and has been considered for outright privatization while retaining the subsidized public service contract (Finn 2008). 
Private operators are given controlled access to the market. In Rostov-on-Don (Russian Federation), the private sector had achieved 63 percent of the market by 2005 within a controlled competition structure (Zyryanov and Sanamov 2007).

Individual minibus operators form associations or cooperatives to gain route contracts or to have access to facilities or finance. In Samarkand and Bukhara (Uzbekistan), independent minibus operators formed associations at the initiative of the municipalities. This gave them access to operating permits and to maintenance and shared purchasing facilities (Gwilliam et al. 1999). In Tbilisi, in 2001, about 3,500 minibus operators consolidated into 64 companies to gain operating franchises from the municipality for 223 lines. The companies were shell companies (i.e., minimal staffing and functions, purely to meet permit compliance, vehicles and staff associated with the entity but remained independent) for convenience. There has not been further integration or consolidation of assets (Finn 2008). In Dhaka, minibus operators formed into cooperatives to be collectively responsible for loan repayments on minibuses made available under a vehicle-leasing scheme sponsored by government (IBIS 2008). The 17 East Jerusalem bus operators formed an association in 2002 and operate under common livery and coordination. This has given them access to two good-quality bus terminal facilities and bus purchase grants from the Israeli Ministry of Transport. In Cebu (Philippines), the jeepney association VUDTRASCO secures operating franchises from LTFRB, and its members then operate under an association franchise covering about 500 units.

Private sector participates directly in infrastructure and rolling stock development and financing. Various financing and investment instruments (PPP, DBOT, BOT, PFI) have been developed to mobilize private finance for major infrastructure projects, such as LRT in Manila. In Fuzhou (China), investors provided direct financing for buses without any participation in the companies or operations and received their payback over the life of the vehicles.

Private sector investors purchase vehicles and lease them to drivers. Tro-tros and taxis in Accra, jeepneys in Manila, marshrutkas in Tbilisi, and shared-taxis in Palestine ("service" taxis) are examples of private individuals purchasing vehicles (usually second-hand) and then renting them to drivers who must pay an agreed amount to the owner (typically per day). In Samarkand and Bukhara, extended families have pooled savings to purchase minibuses, since financing from banks is either not available to them or too expensive.

Operating companies change their business model to gain efficiencies. Bangalore Metropolitan Transport Corporation (India), while remaining in the public sector, 
has restructured its business model along private sector lines. It has outsourced all non-core and many core activities, increased efficiency, and become profitable (Torres 2007). In Indore (India), the city has established a new company that procures all transport and support services from the private sector (Torres 2007). In Dubai, the public transport authority has contracted out the maintenance of all recently acquired buses, being about 1,400 of the total fleet of 1,800 buses. In Ceres (Philippines), the largest private operator of intercity buses has established its own facility to build buses, manufacture spare parts, overhaul major bus components such as engines and transmissions, and make mid-life capital repair.

Table 2 presents a summary of changes in the form of operators and participation of the private sector.

\section{Table 2. Summary of Changes in Form of Operators and Participation of Private Sector}

\begin{tabular}{|l|l|}
\hline \multicolumn{1}{|c|}{ Change in Form of Operator } & \multicolumn{1}{|c|}{ Examples } \\
\hline $\begin{array}{l}\text { Public sector bus operators have their corporate and } \\
\text { ownership basis changed }\end{array}$ & China, Kazakhstan, Tbilisi (Georgia) \\
\hline $\begin{array}{l}\text { Private operators are given controlled access to the } \\
\text { market }\end{array}$ & Rostov-on-Don (Russian Federation) \\
\hline $\begin{array}{l}\text { Individual minibus operators form associations or } \\
\text { co-operatives to gain route contracts or to have } \\
\text { access to facilities or finance }\end{array}$ & $\begin{array}{l}\text { Samarkand and Bukhara (Uzbekistan), } \\
\text { Tbilisi (Georgia), Dhaka (Senegal), East } \\
\text { Jerusalem, Cebu (Philippines) }\end{array}$ \\
\hline $\begin{array}{l}\text { The private sector participates directly in infrastruc- } \\
\text { ture and rolling stock development and financing }\end{array}$ & Manila (Philippines), Fuzhou (China) \\
\hline $\begin{array}{l}\text { Private sector investors purchase vehicles and lease } \\
\text { them to drivers }\end{array}$ & $\begin{array}{l}\text { Accra (Ghana), Manila (Philippines), } \\
\text { Tbilisi (Georgia), Palestine Samarkand } \\
\text { and Bukhara (Uzbekistan) }\end{array}$ \\
\hline $\begin{array}{l}\text { Operating companies change their business model } \\
\text { to gain efficiencies }\end{array}$ & $\begin{array}{l}\text { Bangalore Metropolitan Transport } \\
\text { Corporation (India), Indore (India), } \\
\text { Dubai (UAE), Philippines }\end{array}$ \\
\hline
\end{tabular}

\section{Changes in Transport Supply}

Large-scale expansion of the conventional transport services to meet demand. In many Chinese cities, bus fleets and kilometers operated have more than doubled to meet population growth (Dotson and Finn 2007). In Dubai, as it became clear that a roads-oriented urban transport strategy was failing and congestion levels were unacceptable, bus services have been completely restructured and repositioned. An additional 1,300 new buses have been added to the fleet since 2002, and 
this will increase further in 2009-2010 to provide "feeder" services to the two new Metro lines (Kaiser 2007).

Introduce high quality passenger transport modes. Bus Rapid Transit (BRT) has been implemented extensively in South America and Asia, and now systems are being implemented in the Middle East and Africa.

Large-scale paratransit services are established to replace large-bus services that have failed to expand to meet the increasing travel demand from population growth. Collectivos in Rio de Janeiro, Sao Paolo, Recife, and other Brazilian cities have emerged to provide services from the poor areas (barrios). In Rio de Janeiro, some of the routes have more than 700 vehicles operating on them (Goncalves 2005, Brasiliero 2007). In St. Petersburg (Russian Federation), minibus services (marshrutka) were permitted on fixed routes to complement the conventional services, as the financial conditions did not support bus fleet expansion. By 2002, these services carried 370 million trips annually ( $14.1 \%$ of the total public transport market), more than the trolleybuses and almost as many as the trams (Finn 2003, 2009). In Manila, about 50,000 minibuses (jeepneys) now provide an extensive network of services and are preferred by many users to larger buses and LRT due to their ability to support direct routing without forcing transfers for many or most origin to destination trips.

Large-scale paratransit services emerge to replace large-bus services as they go into decline. In cities of Kazakhstan, marshrutka replaced large-buses on routes where they ceased to operate or offered insufficient service. In general, they did not attack routes where buses continued to operate. (Finn 2005, 2008). In Ghana, Senegal, Tbilisi, and Santiago de Chile, paratransit that initially emerged to fill service gaps became the dominant form of transport and in some cases effectively "killed" the remaining large-bus service.

Shared taxis emerge to complement large-bus transportation or meet specific needs. In Amman, about 3,200 licensed shared taxis now operate on 70 fixed routes from the center to designated suburbs, on a fill-and-go principle. The shared taxis carry more passengers daily than the current underdeveloped large bus network. In Ghana, in the rural areas and villages, shared taxis (cars) provide an equivalent service to the minibuses and are the dominant form of public passenger transport (Finn 2008).

Large bus services are restored when the city or operator regains financial and/or organizational capacity. In Ghana, the government facilitated the emergence of 
a new large bus company, leveraging private and public financing. Metro Mass Transit now has in excess of 500 large buses and operates services in the main cities and on intercity routes. It has regained 15-20 percent of the market share in Accra (Finn 2008). In Kaunas, the refinancing of the municipal bus company's fleet (referred to in Table 1) had the specific objective to restore large bus operations and reduce minibus operations. The market share of the large bus sector increased from 50 to 90 percent (Bruggeman 2009). In Tbilisi, the municipality has funded the acquisition of more than 600 vehicles for the Tbilisi Bus Company (TBC), a mix of second-hand large buses and new mid-sized buses. TBC has restored service on all main routes and has improved from a 5 percent market share in 2001 to close to 50 percent, at the expense of minibuses (Finn 2008). In Cebu, all public transport is currently provided by jeepneys or taxis. BRT is planned, which will introduce urban large-bus operations.

Table 3 presents a summary of changes in transport supply.

\section{Table 3. Summary of Changes in Transport Supply}

\begin{tabular}{|l|l|}
\hline \multicolumn{1}{|c|}{ Change in Transport Supply } & \multicolumn{1}{c|}{ Example } \\
\hline $\begin{array}{l}\text { Large-scale expansion of the conventional transport } \\
\text { services to meet demand }\end{array}$ & Chinese cities, Dubai (UAE) \\
\hline Introduce high quality passenger transport modes & $\begin{array}{l}\text { South America, Asia, Middle East, } \\
\text { Africa }\end{array}$ \\
\hline $\begin{array}{l}\text { Large-scale paratransit services are established to } \\
\text { replace large-bus services that have failed to expand to } \\
\text { meet increasing travel demand from population growth }\end{array}$ & $\begin{array}{l}\text { Rio de Janeiro, Sao Paolo, Recife } \\
\text { (Brazil), St Petersburg (Russian } \\
\text { Federation), Manila (Philippines) }\end{array}$ \\
\hline $\begin{array}{l}\text { Large-scale paratransit services emerge to replace large- } \\
\text { bus services as they go into decline }\end{array}$ & $\begin{array}{l}\text { Kazakhstan, Ghana, Senegal, Tbilisi } \\
\text { (Georgia), and Santiago (Chile) }\end{array}$ \\
\hline $\begin{array}{l}\text { Shared taxis emerge to complement large-bus transpor- } \\
\text { tation or to meet specific needs }\end{array}$ & Amman (Jordan), Ghana \\
\hline $\begin{array}{l}\text { Large bus services are restored when city or operator } \\
\text { regains financial and/or organizational capacity }\end{array}$ & $\begin{array}{l}\text { Ghana, Kaunas (Lithuania), Tbilisi } \\
\text { (Georgia), Cebu (Philippines) }\end{array}$ \\
\hline
\end{tabular}

Tables 1, 2, and 3 show that the changes can be wide-ranging and that individual countries experience more than one type of change. 


\section{Success Factors for Change}

The cases presented in this paper indicate a very wide range of contexts and mechanisms. Each has been implemented with the objective either of strengthening the sector or of making a practical response to challenges within prevailing constraints. The changes considered in this paper primarily have had the objectives of reforming or strengthening public policy and/or the operator organizational framework. In this context, an outcome is deemed "successful" where improvements to urban bus service ridership, mode share, public transport quality, new investments, financial sustainability, or its profitability has resulted from changes in either framework or operator organisation level.

The principal stimuli for successful implantation of planned structural change are a leading political vision and/or policy, such as urban spatial development or economic regeneration; a need to respond to rapid growth in demand for passenger services due to population growth; a need to respond to serious challenges such as traffic congestion or air quality; a recognition that major infrastructural projects such as BRT cannot be implemented until the regulatory framework or operator structure/quality is improved; or a need to respond to serious degeneration of the available passenger transport services.

A number of contributing success factors emerge from the cases discussed here and elsewhere (Finn and Walters 2010) for building on the structural change to develop urban transport services in general in cases where they are currently underdeveloped, fragmented, or of low quality. These include:

- Presence of strong political leadership and support.

- Explicit, local urban transportation strategies and programs implemented within the context of national plans and strategies which have already been approved by the national government.

- Establishment of an effective regulatory framework defining responsibilities, roles, market access, and rights of initiative, with sufficient legal backing.

- Establishment of an empowered regulator with appropriate structure, technical capacity, continuity, and institutional memory.

- Development of the human and organizational capacity of the regulator.

- Establishing and maintaining real consultation and collaboration with the key stakeholders, especially the operators and impact communities.

- Organization of a controlled transport market with quality-based entry, supported by an effective enforcement capacity.

- Establishment of contractual or agreement-based relationships. 
- Creation of effective mechanisms to align supply with demand and to stimulate investment/provision of increased resources where they are required.

- Development of the business and operational/technical capacity where the operator sector is already fairly well structured.

- Where the operator sector is fragmented, consolidation to facilitate economies of scale, increase professionalization, and access finance.

- Financial and other stimulus measures to encourage operators to upgrade and improve.

While many of these factors that successfully facilitate change might also apply to developed countries, the policy, institutional, regulatory, and fiscal frameworks in developing countries are already in place and are stable. In contrast, in developing countries and countries in transition, it is usually necessary to implement or enhance one or more of these frameworks before progress can be made to improve urban bus services. In extreme cases, it is necessary to establish a complete framework from scratch as well as build competency (in both framework and operational arenas) before the benefits can be realized from improving urban bus services more generally.

The successful implementation of these factors confronts the informal minibus, paratransit sector that has played a very important role in some, but not all, urban areas in developing and transition countries. Where they are already established, a number of factors determine their future development and, in some cases, their survival as significant transportation services. These include:

- The attitude of the authorities, in particular whether they accept the presence of this transportation mode (as in Ghana, Kazakhstan, Philippines, South Africa), whether they wish to contain it in a reduced or transformed role (as in St. Petersburg), or whether to systematically replace it (as in Kaunas, Tbilisi).

- Whether the services are seen as a permanent feature of urban transport provision or something transient. For example, in Ghana the services have been operating for at least a quarter century and are well understood by the population, and the routes are well known and, as a result, are now seen as a permanent feature; in the Philippines, jeepneys are accepted by both authorities and passengers as an integral feature of urban transport and culture.

- The willingness of the authorities to develop a formal regulatory framework within which the paratransit services can operate and develop, as part of their policy for the urban transport sector (as in South Africa, Philippines). This is in contrast to the developed world, where many policy-makers and 
regulators consider these services to be primitive and "inappropriate" for their cities and regulate to prevent their emergence and have effective penalties in place should they emerge illegally.

- The ability of this sector to evolve from operational collectives of individuals into companies that can invest in vehicles, rationalize and optimize resources, and develop their business capacity. Despite high revenues in the sector, business evolution has not been observed, which will inevitably impact the potential longevity of operation.

- The ability and willingness of this sector to invest in continuous product improvement, especially in newer vehicles, professionalization of drivers, and better maintenance, so as to evolve from a low-cost, low-quality product to something citizens would use by choice.

- The determination to improve service quality and reliability and to integrate with other transport modes operating in the urban area. In South Africa, paratransit services and providers are being integrated into the BRT system. The restructuring of urban transport in St. Petersburg included the marshrutka as part of the planned supply. It occurs informally in Amman, where the shared taxis operate from bus terminals, and in Brazil when collectivos bring customers to Metro and large bus transfer points.

\section{Conclusions}

This paper has developed a framework for classification of changes in the urban passenger transport sector in developing countries and countries in transition with three elements: change in the role of the regulator/transport authority, change in the form of operators, and change in transport supply. Each element is illustrated with evidence, showing the way in which regulators and markets, the form of operators, and the supply of transport have changed in response to contextual change and highlighting the very many different ways in which sectors respond. It reveals that change, whether legislative or policy, does not lead to a unique response.

The practice presented in this paper shows commonality in the desire for change but distinct differences in policy and outcomes. This allows the factors that are evident in successful outcomes to be identified. It also establishes the importance of the minibus, paratransit, and informal sectors in the process of change in many countries and the issues that affect whether this sector is likely to be a permanent or transitory feature of the urban transport sector supply. 


\section{References}

Amos, P. (2004). Public and private sector roles in the supply of transport infrastructure and services: Operational guidance for World Bank staff. World Bank, Washington.

Brasiliero, A., C. Guerra, and J. Aragão. (2007). Regulatory reform of the urban bus system in Recife (Brazil): Stakeholders and constituency building process. Proceedings of 10th International Conference on Competition and Ownership in Land Passenger Transport, Hamilton Island.

Bruggeman, G. (2009). Kaunas - A new framework for public transport. Thredbo 11 Conference, Delft, Netherlands.

Carvalho, W., R. da Cruz, M. Câmara, and S. de Aragão. (2009). Rural school transportation in emerging countries: The Brazilian case. Thredbo 11 Conference, Delft, Netherlands.

Dotson, E. and B. Finn, B. (2007). An overview of ownership and market reform of urban bus service in Chinese cities. Proceedings of 10th International Conference on Competition and Ownership in Land Passenger Transport, Hamilton Island.

Filho, R. O. (2007). Urban transport in South America: Trends in competition and competition policy. Proceedings of 10th International Conference on Competition and Ownership in Land Passenger Transport, Hamilton Island.

Finn, B., and J. D. Nelson. (2003a). An international perspective in the changing structure of the urban bus market: Transit planning and development, management and performance, marketing and fare policy. Transportation Research Record 1799.

Finn, B., and J. D. Nelson. (2003b). A functional model for an urban passenger transport authority. Competition and Ownership in Land Passenger Transport: Selected Refereed Papers from the 8th International Conference (Thredbo 8), Rio de Janeiro.

Finn, B. (2005) 'Transition from public monopoly to controlled competition in a post-socialist economy: Experience in the Republic of Kazakhstan. Selected Papers from the 9th International Conference (Thredbo 9), Lisbon, September: 659-676. 
Finn, B. (2008). Market role and regulation of extensive urban minibus services as large bus capacity is restored: Case studies from Ghana, Georgia, and Kazakhstan. Research in Transport Economics: 118-125.

Finn, B. (2009). What can European and North American cities learn from largescale paratransit in the rest of the world? Transportation Research Board 88th Annual Meeting, Washington.

Finn, B., B. A. Arthur, and S. Gyamera. (2009). New regulatory framework for urban passenger transport in Ghanaian cities. Thredbo 11 Conference, Delft, Netherlands.

Finn, B., and J. Walters. (2010). Workshop report - Public transport markets in development. Research in Transport Economics, Elsevier, doi:10.1016/j. retrec.2010.07.045

Gonçalves Pereira, C., A. de Araújo, M. Braga, and R. Balassiano. (2005). Paratransit regulation in Rio de Janeiro: A comparison of two surveys. Proceedings of 9 th International Conference on Competition and Ownership in Land Passenger Transport, Lisbon.

Gwilliam, K. G., R. T. Meakin, and A. Kumar. (1999). Designing competition in urban bus passenger transport: Lessons from Uzbekistan. 6th International Conference in Competition and Ownership in Land Passenger Transport, Cape Town.

Gwilliam, K. G. (2003) Bus franchising in developing countries: Recent World Bank experience. Competition and Ownership in Land Passenger Transport: Selected refereed papers from the 8th International Conference (Thredbo 8), Rio de Janeiro.

Gwilliam, K., L. Zhu, and B. Finn. (2009). Recent developments in bus transport in China. Thredbo 11 Conference, Delft, Netherlands.

IBIS Transport Consulting. (2008). Dakar bus financing study, final report. Unpublished report for the World Bank.

Kaiser, J. (2007). Dubai public transport bus master plan: A new era of public transport services in the world's fastest developing city. Proceedings of 10th International Conference on Competition and Ownership in Land Passenger Transport, Hamilton Island. 
Kumarage, A. S., and M. D. R. P. Jayaratne. (2007). Lessons in ownership, regulation and management from 100 years of bus transport in Sri Lanka. Proceedings of 10th International Conference on Competition and Ownership in Land Passenger Transport, Hamilton Island.

Kumurage, S. J. Weerawardena, and R. Piyasekera. (2009). A concession model to promote rural bus services in Sri Lanka. Thredbo 11 Conference, Delft, Netherlands.

Muňoz, J. C., and A. Gschwender. (2007). TranSantiago: A tale of two cities. Thredbo 10 Conference, Hamilton Island, Australia

Nielson, G., C. Mulley, J. Nelson, G. Tregner, G. Lind, and T. Lange. (2005). Public transport-Planning the networks. HiTrans Best Practice Guide 2.

Richmond, J. (2006). Mauritius transport consensus forums. Briefing note to Cabinet of the Government of Mauritius.

Torres, M. (2007) Innovative public-private sector cooperation in urban transport in India. Transportation Research Board 86th Annual Meeting, Washington.

Walters, J. (2009). Is the bus contracting system in South Africa leading to trusting partnerships between contracted parties? An analysis of funding issues and the impact on relations between government and operators. Thredbo 11 Conference, Delft, Netherlands.

UITP. (2003). Better urban mobility in developing countries: Problems, solutions, good practices. Brochure, http://www.uitp.org/publications/brochures/index. $\mathrm{cfm}$.

UN. (2005). Johannesburg plan of implementation of the world summit on sustatinable development. UN Department of Economic and Social Affairs, http:// www.un.org/esa/sustdev/documents/WSSD_POI_PD/English/POIToc.htm.

World Bank Group. (2008). Safe, Clean and affordable transport for development: The World Bank Group's transport business strategy for 2008-2012. World Bank, Washington.

Zyryanov, V., and R. Sanamov. (2007). Improving urban public transport operation: Experience of Rostov-on-Don. Proceedings of 10th International Conference on Competition and Ownership in Land Passenger Transport, Hamilton Island. 


\section{About the Authors}

Brendan FinN (etts@indigo.ie) is a Transport Consultant specialising in institutional and regulatory frameworks and reforms for urban passenger transport, in public transport operations, and in ITS. He has undertaken many related assignments in Europe, Middle East, CIS, China, South-East Asia, and Africa. His current research is motivated by the need to identify effective strategies for policy-makers, transport authorities and transport operators in developing countries and countries in transition, bearing in mind that often the most relevant examples are in other developing/transition countries but are usually not well reported in the literature. $\mathrm{He}$ is currently working on projects with BRT components, which usually require development or strengthening of the institutional and regulatory framework, and of the operational and financing structures and capacity of the operator sector.

Corinne Mulley (corinne.mulley@sydney.edu.au) is the founding Chair in Public Transport at the Institute of Transport and Logistics Studies. As a transport economist she has researched and published at the interface of transport policy and economics, in particular on issues relating to public transport. She led a high profile European and UK consortia undertaking benchmarking in urban public transport and has provided both practical and strategic advice to local and national governments on benchmarking, rural transport issues, and public transport management. Her research is motivated by a need to provide evidence for policy initiatives and she has been involved in such research at local, regional, national and European levels. She has an enduring interest in modern transport history and in the way this can inform current thinking about policy. 